\title{
The Impact of Public Relations Principles in the Strategic Management of the Police Force in Kenya
}

\author{
Debora Mary Muchilwa ${ }^{1}$, Odoyo Collins Otieno ${ }^{2, *}$, Moses Oginda $^{2}$, David Oima $^{1}$ \\ ${ }^{1}$ Department of Marketing and Management, Maseno University, Kenya \\ ${ }^{2}$ Department of Management Sciences, Masinde Muliro University of Science and Technology, Kenya \\ *Corresponding Author: odoyo08@yahoo.com
}

Copyright (C 2014 Horizon Research Publishing All rights reserved.

\begin{abstract}
Public Relations is a department which has not been effectively utilized in the public sector, particularly in the police force in Kenya. One can hardly find it clearly defined and stipulated in the statutes and organizational structures of the various public institutions. Its presumed non-existence has resulted to lack of aggressiveness and low morale among staff members, negative publicity and bribery incidences in the forces, increased insecurity, negligence and public demonstrations as witnessed in Kenya during the 2007 post election violence. This study sought to determine the effect of public relations principles in the management of the police force in Kenya. This study used cross sectional data. The study target populations were four (4) police stations in Kisumu police division comprising of approximately 330 staff members of the force in the four stations under KPD (this figures are as at October 2008). Given the numbers involved and sensitivity of information in the police force, convenience and simple random sampling were used for the study. A reconnaissance study done in October 2008 confirms the availability of respondents to provide data required. Descriptive statistics was used to analyze the data, which was presented in the form of frequency tables and bar charts. The data for the study reported that only top-level management was involved in planning activities. Majority $(59.03 \%, \mathrm{n}=98)$ of the respondents seemed to be of the opinion that the effectiveness and efficiency of the planning process including policy formulation and analysis was on the average. The media was most involved in informing management on PR as stated by $59.03 \%$ of the respondents. The study recommends that facts gathering instrument like conducting of interviews, literature review, observation and informal conversations be used so as to be able to collect appropriate data. This is because Radio/TV alone cannot offer holistic information on the PR situation. It would thus be important to conduct full surveys and to produce reports so as to accurately present the PR situation.
\end{abstract}

Keywords Public Relations, PR, Kisumu Police Division, KPD

\section{Introduction}

Public Relations is a continuous and systematic process that involves multiple publics and provides advice to the management of an organization concerning policies, relationships and communication. It is a planned and sustained effort to establish and maintain goodwill and mutual understanding between an organization and its publics (Jefkins, 1998). It is used here as an activity that seeks to establish good relationships and understanding based on facts, knowledge and information. Public relations in this study will be characterized by research, planning, counseling and anticipation of public opinion.

Public Relations (PR) is not a recent profession. It has existed since 1890 when Lloyd George used it to explain the new old age pension. The First World War also employed a lot of public relation activities through the establishment of information services and ministries of information for the purpose of publicity (Puri, 1995). With increasing PR activities the world over, many PR organizations such as International Public Relations Association (IPRA) and the Public Relations Society of Kenya (PRSK) have now been established. Public relations departments have also been created in the private and public sectors including public universities and the police force.

In developing countries, PR is extensively used in the police force not just for media relations but also in preventing or reducing crimes through the organization of special events in which participants secure sponsors and hand out crime prevention tips from the local police department which educates citizens on how to make their community safer and raise money for community crime prevention. PR has further been used in organizing for police volunteer programs and in assisting the police work in partnership with community groups. Police Agencies have established public information officers who communicate with a variety of audiences, particularly the media. This has resulted in moving law enforcement from a closed to a more open system of communication (New York, Police quarterly, 2002).

PR is practiced extensively in Kenya today, as evidenced 
by the number of people serving as public relations officers, information officers and PR consultants. The establishment of Kenya Institute of Mass Communication (KIMC) is indicative of the positive attitude towards information, media and the need to enhance communication in an African context with a widely scattered and often newly literate, or semi-literate population (Black, 1991). In Kenya, we have approximately three hundred (300) stations of the police force, (Kenya police standing orders). To enhance its performance and improve on its PR the police force has thus restructured its organization setup to include the position of the public relations officer also known as police spokesman. At Kisumu Police Division we have a customer care desk which serves as an information desk, though, media relations are normally handled by the Officer Commanding the Police Division (OCPD). However, it is not clear if the customer care desk applies other PR principles besides dissemination of information.

One important function of $\mathrm{PR}$ is anticipating public opinion. For effective anticipation of public opinion, the PR department must deal with real and perceived public opinion as they establish and maintain relationships with their many internal and external publics (Black, 1972). If public opinion is not anticipated, then there will be no dynamic process of any interpersonal and media communication on issues, resulting in misunderstanding.

Administrators need to understand the attitudes and values of their publics in order to achieve organizational goals, and counseling is extremely vital in this area. A PR practitioner acts as a counselor to management and as a mediator helping to translate aims into reasonable and publicly acceptable policies and actions. (Drucker, 1954). Without the counselor, the management may not adequately inform the members of the organization about the laws and regulations and the effect of those laws on their lives. He or she may misjudge the possible reactions of the members about the proposed laws and policies of the organization.

The issue of planning is critical to any management undertaking. For effective planning, the role of PR is very crucial. Planning is about taking steps to agree on the resources; that is, the means by which the aims and objectives may be fulfilled (Michael, 2008). Part of this process includes deciding on the policies which will guide the implementation of the plans. Planning is essentially a cyclical and an ongoing process in which aims and objectives are regularly reviewed and where the progress of plans are subjected to frequent review and updating in the light of results (cole,1979).

The other important function of PR is research. For effective research, the PR department should listen to the complaints, compliments, enquiries, request, and suggestion of both the internal and external public. Complaints should be investigated and errors corrected, compliments should be acknowledged and passed on to those directly concerned while enquiries, requests and suggestions should be considered conscientiously and acted on promptly (black, 1972). All these will lead to excellent management practices that will strengthen the reputation of an organization or institution such as the police force in the eyes of the individuals concerned. Without research, it would be difficult to diagnose the problems of the institution (police force). It becomes impossible to know how popular an institution is with its customers and other publics with whom its directly involved. Research is particularly significant to the police force considering the fact that they are law implementers and they need to integrate the publics' complaints, compliments and suggestions in the formulation of their laws and policies.

Management refers to the process of forecasting, planning, organizing, commanding, coordinating and controlling (Fayol, 1987). Management will be operationally defined as crisis solving, communication output, decision making and implementation.

Although PR is accepted as an important tool in management, the extent to which it has been used and appreciated in the management of the police force is not clear. No clear mandate has been outlined in the management of the police force on how they use PR to plan for their daily operations. This scenario suggests the need for a study to address the effect of PR principles in the management of the police force.

\section{Literature Review}

Management is about forecasting, planning, organizing, commanding, coordinating and controlling (Fayola 1987). Fact finding, counseling and gauging the attitudes of both the internal and external public conclusively helps in coming up with an inclusive plan, which will in essences be easier to organize, coordinate and control since it encompasses the opinions of all those that may be affected.

PR has developed very rapidly in recent years, partly because management of various commercial and non-commercial organizations has discovered a need for PR activities. Government and Public services have being among the leading users of PR techniques. According to Jefkins, (1994) Lloyd George, Chancellor of exchequer in the UK used PR to research and give an explanation on the new old age pension scheme. In 1912 the first president of International Public Relations (IPR) Sir Stephen Talent used PR to promote the empire marketing board between 1926 and 1993. In the UK, PR played an increasingly important role in creating understanding in industries such as Tele-communication, supermarkets and insurance companies. Telecommunication companies used PR Specialists to launch new products.

The PR tool effectively implemented can help correlate the private interest and to facilitate the growth and development of that particular organization. The relationship between good management and employee relations to job satisfaction and other organizational outcomes are indicators of organizational effectiveness. Similarly, research has shown that PR is a public function. It plays several roles of 
advising and supporting top officials (Cutlip et al., 1985). Like managers PR executives may be too closer to situation to maintain an objective point of view. PR can thus influence organizational actions by demonstrating the ability to produce results in accordance with the organizational goals.

Every organized effort to influence public opinion on specific target groups, directly or through the media, involves the use of PR strategies and tactic. Despite the growing influence of PR, however, little application of PR theory and research has been integrated into the study of political campaigning and political marketing process. Political marketing as a professional practice use public relations strategies and techniques. Political marketing would benefit from an integration of public relations theory and research in which four public relations theories relationship theory. Contingency theory, situational theory of publics and agenda building theory should be of particular interest. The contingency theory of accommodation in PR points that the practice of PR moves on a continuum from total advocacy for an organization to total accommodation of a public (Grunig and Hunt, 1984). From an agenda building perspective, the primary role of political public relations is in shaping the media agenda, although it is crucial to recognize its contribution to image management, internal party communication and government information management (Otis et al., 1995). Political PR efforts contribute to the media agenda through the use of information subsidies in the form of news releases, debates, press conferences and interview, among others. Political marketing as a professional field of activity and an academic field of research would benefit from a broader and deeper understanding of modern PR theories as it involves building long term relationships.

Generic principles of Excellent PR in a different cultural context, a case study of Singapore analyzed four generic principles of PR based on the Excellency Theory to analyze the extent to which strategic PR management was practiced in Singapore and whether PR is part of senior management in different types of organizations.

Norman Hart (1995) in his book, focused on strategic management where he looked at the introduction to the concept and practice of strategic planning for a business and the relationship of public relations to the achievement of corporate goals.

Otis; et al on the other hand studied the theories used in PR and adopted Grunig's model of PR to illustrate the different ways organizations relate with their publics. Further, they studied the use of public relations in not -profit organizations where realization of the necessity for consistency in their relationships with various publics, membership recruitment or retention and fundraising basically depended on the proper use of PR. PR in government keeps public informed about issues, problems and actions at all levels of government. PR helps in gaining support foe new laws or initiatives, stimulating citizen interest and relieving public confusion about government agencies, processes and programes, facilitating voter decision making by providing factual information and by enabling citizens to use government services fully by providing continuous information. According to Paul Christ (2009), PR involves the cultivation of favorable relations for organizations and products with its key public through the use of a variety of communication channels and tools such as media relations, media tours, newsletters, special events and sponsorships. PR building awareness and a favorable image for a company or client within stories and articles found in relevant media outlets and closely monitoring numerous media channels for public comments about a company and its products. Further, PR supports marketing by managing crisis that threaten company or product image and by building goodwill among an organization's target market through community, philanthropic and special programmes and events.

\subsection{Effect of Research Role of $P R$ in Management}

Brooms and Dozier, (1990) established that research is basically about fact generating in relation to a problem. In evaluation research, an important activity taken by PR practitioners is fact gathering. These facts are gathered through interviews, from library material and through informal conversation (Lesley, 1991). It also involves the use of survey techniques and firms specializing in designing and conducting opinion research. After a program is completed, the PR practitioner studies its results and evaluates the programs planning, implementation, and effectiveness.

According to Black, (1991) information gained through careful research can be used to guide planning, pre-test messages, evaluate results, and direct follow up efforts without a basis in research, PR can be a little more than a low - level activity in support of some management decision in which very few people participate. Research is therefore a vital function in the process of PR (Black, 1991). PR is essentially an art of persuasion, and in order to influence people, it is obviously helpful to know as much as possible about the way in which people think and the manner in which they react to particular circumstances prompting the necessity of research.

\subsection{Effect of the Planning Role of $P R$ in Management}

Another tool used in PR practices is planning. It provides a sense of direction, focused efforts and helps an organization to evaluate their progress Fayol (1987). It is essential in controlling. According to Cole (1979) planning is an activity which involves decisions about ends (organization aims/objectives), means (plans), conduct (policies), and results. It is an activity that takes place against the background of the organization's external environment and the organization's internal strength and weaknesses. It can be long term as in strategic and corporate planning or short term as in the setting of annual departmental budgets.

Cole further explained planning as a management activity, which begins by defining the aims and objectives of the 
organization. Planning is also about taking steps to agree on the resources, that is, means by which the aims and objectives may be fulfilled. Part of this process includes deciding the policies, which will guide the implementation of the plans, that is, the manner in which aims and objectives are regularly reviewed and where the progress of plans are subject to frequent review and updating in the light of results. Jefkins (1994) defines PR as "a planned and sustained effort to establish and maintain goodwill and mutual understanding between an organization and its publics". In this study, planning will be referred to as the process of goal setting and choosing the means to achieve those goals effectively and efficiently.

PR effectiveness depends on good planning. Good planning is the best way to practice preventive rather than remedial PR. Planning provides the opportunity to involve management from other areas of the organization and to ensure their cooperation and support. Planning always involves the future. Predicting aids and barriers that will exist in the future is more difficult than evaluating the existing situation, yet such predictions are necessary to determine the effects of anticipated conditions on the programs being planned.

\subsection{Effect of the Counseling Role of $P R$ in Management}

Besides planning and research, counseling is also another tool PR practitioners use to determine impact of PR. It is of prime importance to recognize that counseling is not intended to do anything to individuals; its role is to enable them to get their problems into perspective and to see what they themselves can do to solve them (Cutlip et al., 1985). In counseling, modern PR calls for people with a holistic view of business who can act as advisers to management on a great variety of issues. PR seeks to give continuous information to people regarding laws, plans and achievements of organizations (Black, 1991). It tries to inform the public regarding the laws, regulations and such matters that affect daily life of the citizen as well as advising the management at all levels regarding the likely reactions of the people to proposed laws and policies of the organizations (Puri, 1995). Counseling as a PR tool entails advising management on what needs to be done and the expected reaction towards various proposals.

\subsection{Effect of Anticipation of Public Opinion in Management}

Anticipation of public opinion may vary and may as well be classified under the various images that exist to include multiple, which and mirror images, among others. From the definition given by (Jefkins, 1994) in the introduction, PR is about communication management. Effective PR will ensure that the public that is important to the organization is no longer ignorant of the organizations good points, of its special strengths, achievements and the difficulties that it is meeting and have overcome. The result of this increased knowledge will be greater understanding of the organization's problems and greater appreciation of its achievements, hence a positive public opinion. Further, basing on anticipatory roles, PR officer's task in this case is to identify how publics will react to particular events (Baines, 2004). PR techniques are used to reduce negative association as well as create positive ones. This is done by attempting to create understanding. PR officer's task is to move public opinion from down-right hostility, through prejudice, apathy, and ignorance towards interest, acceptance, sympathy and ultimately knowledge. The PR officer helps the public become more knowledgeable about the organization and its perspective. (Howard, 1992) argues that PR strategies should aim to enhance motivation and ability to process information, that is, information that addresses concerns and clarifies misunderstanding. In general, it is evident that despite a few differences in the management of PR, its key role is establishing and maintaining mutual beneficial between an organization and its public. In conclusion, from the preceding literature, very little seems to have been done on the application of PR principles in management and particularly management of the police force. Many authors have made attempts to define the PR discipline, though the definitions are quite diverse. Research also seemed to have focused more on business organizations. Research done so far has focused more on application of PR in marketing and political communication and the role played by public relations in government and nonprofit making organizations. Planning and research have been used to aid in the achievement of corporate goals. However, no mention has been made on how counseling, research, anticipation of public opinion and planning are applied in the police force.

It is therefore necessary that research on the effect of PR principles in the management of the police force be carried out. This will help unearth the hidden roles of PR principles in the institution and how PR can effectively serve the police force in dealing with public demonstrations, students riots, effective handling of criminals in the police cells and proper planning of police operations.

\section{Methodology}

The study area was in Kisumu District in Nyanza Province and targeted Kisumu Police Division (KPD). KPD is located at Kisumu Central Police station which is situated behind Imperial Hotel and opposite Coca-cola bottlers approximately $1 \mathrm{Km}$ from the Central Business area. KPD comprises four (4) police stations which operate under the Officer Commanding Police Division (OCPD). A cross sectional survey research design was adopted. The target population comprised four police stations in KPD comprising of approximately 330 staff. That is, 161 staff of Kisumu central, 69 from Maseno, 80 from Kondele and 20 from Miwani police stations. Given the sensitivity of information in the police force, this study employed convenience sampling for the staff and persons in police 
custody where the respondents were chosen according to their availability. The study used majorly the primary data which was collected using two structured and unstructured questionnaires issued to the members of the police force in KPD.

Quantitative data was analyzed using Statistical Packages for Social Sciences in which descriptive statistics was used to arrive at frequency distributions. Qualitative data was analyzed by coding and organizing data into themes and categories then evaluating the usefulness of information for answering research questions. Data was presented in the form of frequency tables and bar charts to enable the researcher and other readers to be able to compare the popularity of the individual principles of PR.

\section{Discussion}

In determining the effect of PR principles in KPD it was found important to find out the background information of the respondents. According to the findings the age distribution of the respondents according to sex was as illustrated in Table 1 below.

Table 1. Distribution of Respondents according to Age and Sex

\begin{tabular}{cccc} 
Age & Male & Female & TOTAL \\
\hline 20-30 Years & $18(10.84 \%)$ & $16(9.63)$ & $34(20.48 \%)$ \\
30-40 Years & $33(19.87 \%)$ & $23(13.85)$ & $56(33.74 \%$ \\
40-50 Years & $32(19.27 \%)$ & $18(10.84 \%)$ & $50(30.12 \%)$ \\
Above 50 Years & $17(10.24 \%)$ & $9(5.42 \%)$ & $26(15.66 \%)$ \\
\hline TOTAL & $100(60.24 \%)$ & $66(39.76 \%)$ & $166(100 \%)$ \\
\hline
\end{tabular}

Source: Respondents scores, 2008

Table 1 above shows majority $60.24 \%(n=100)$ of the respondents were male while $39.76 \%(\mathrm{n}=66)$ were female. This depicts majority of the staff in KPD are males. The findings also revealed that majority of $19.87 \%(n=33)$ of the respondents were Males aged between $30-40$ years of age while almost a similar proportion $19.27(\mathrm{n}=32)$ being males aged between 40 to 50 years. It was also worth noting that most female respondents i.e $13.85 \%(\mathrm{n}=23)$ of the total number of respondents were aged between 30 to 40 years of age. This depicts that majority of the staff in KPD were middle aged thus had a potential to serve the police force for a long period.

A significant proportion $20.84 \% \quad(\mathrm{n}=34)$ represent respondents who were aged between 20 to 30 years. This represents a large battalion of police officers who have been recruited into the police force. The differential population in the number of male and female police officers could be attributed to the fact that there still exists a gap between educated boys and girls that still manifests itself in the workplace.

It was further considered essential to establish the level of training and education of the respondents. This was so as to establish a correlation between the general level of education and the effect of PR principles. The findings to the respondent's level of education were as illustrated in Figure 1 below.

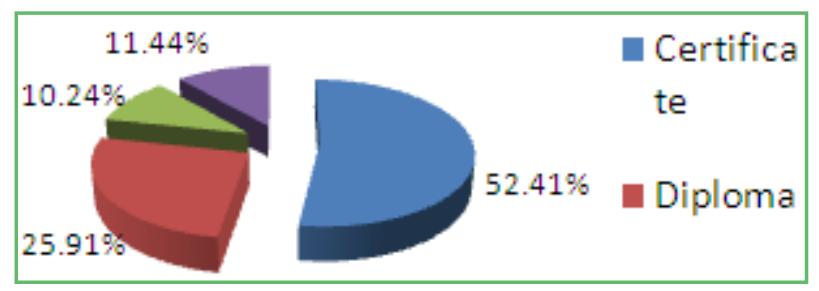

Source: Respondents scores, 2008

Figure 1. Highest Level of Education

Figure 1 above illustrates that majority $(52.41 \%, \mathrm{n}=87)$ of the staff had attained certificate from the police force training college while $25.91 \%(\mathrm{n}=43)$ had attained college diploma. A considerable proportion $(21.68 \%, n=36)$ of the KPD staff were either holders of bachelors degree $(10.24 \%$, $\mathrm{n}=17)$ or a masters degree $(11.44 \%, \mathrm{n}=19)$. This shows that a significant proportion of the KPD staff were well educated.

Looking at the number of years KPD staff had served in the force. Majority $(51.20 \%, \mathrm{n}=85)$ had served for more than 10 years, $(21.08 \%, \mathrm{n}=35)$ had served for $7-10$ years and only $(8.43 \%, \mathrm{n}=14)$ had worked for $1-3$ years. This implies that most of the KPD staff, including certificate and diploma holders, had served for more than 10 years in the police force thus are more experienced on the PR in the force.

\subsection{Effect of the Research role of $P R$ on the Management of KPD}

As stated in the literature review, research is a vital function in the PR process. Research makes PR "a little more than a low-level activity in support of some management decisions in which very few people participate." In order for the research role of PR to be effective in KPD, research has to be continuously carried out. It was therefore sought to establish the various research instruments used by PR in KPD and the findings were as illustrated in Figure 2 below.

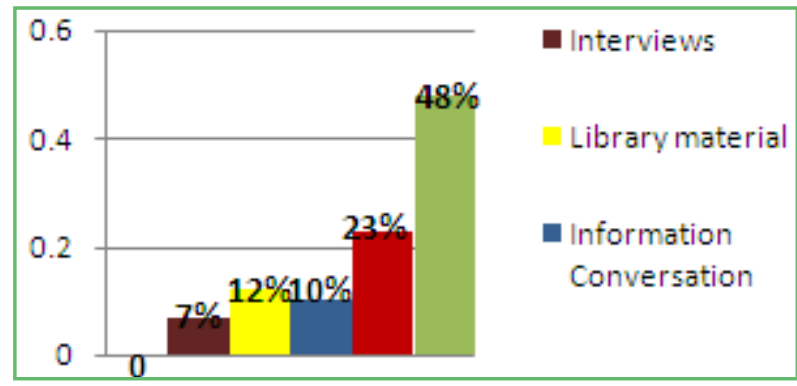

Source: Respondents scores, 2008

Figure 2. Research Instruments used by PR in KPD

Figure 2 above illustrates that majority of the respondents (48\%) used radio/TV as the research instrument in PR, 23\% used print media while $12 \%$ used library material. The use of radio/TV as the preferred research instrument could be attributed to the proliferation of communication technology 
in this and other areas of the region.

After establishing the research instruments used by public relations in KPD, the study sought to find out how the respondents rated the importance of research in PR of KPD and the findings were as illustrated in Figure 3 below.
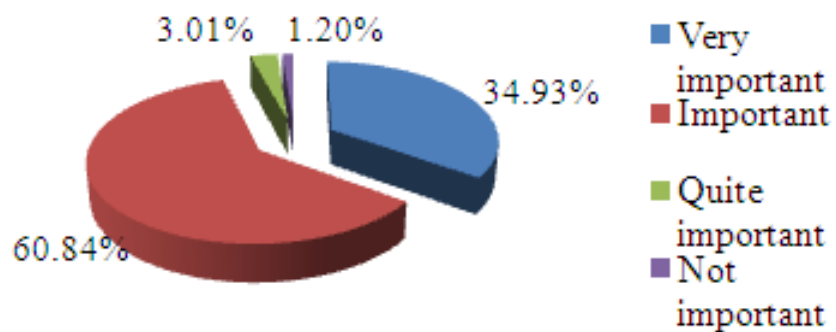

Source: Respondents scores, 2008

Figure 3. Importance of Research in PR in KPD

Figure 3 above illustrates that majority $(60.84 \%, n=101)$ of the respondents were of the opinion that research was important in PR while $34.93 \%(n=58)$ stated that it was very important.

Having found out that a large proportion $(95.77 \%)$ of the respondents considered research to be either very important or plain important the study sought to find out the level of involvement in research activities of the respondents. The study adopted a five point Likert scale to measure the various variables in the study. Descriptive statistics which comprised measures of Central tendency, dispersion, frequency and percentages were computed. The key to the scale index used in the Four point Likert scale was as follows; majorly involved, Involved, Minimally Involved and Not Involved.

Table 2 shows that a large proportion of the respondents were involved in program implementation (53.61\%), Fact gathering $(37.95 \%)$ and many were not involved in evaluation of results $(42.77 \%)$, and program planning $(53.61 \%)$.

The level of involvement in research having been found the study sought to establish how PR principles were applied in the management. The study also adopted a five point Likert scale to measure the various variables in the study. The key to the scale index used was as follows: Strongly agree $=5$, Agree=4, Not sure=3, Disagree=2, Strongly disagree $=1$.

Table 3 show that most of the respondents agreed with the fact that the PR officer studies the PR results and evaluates the programs planning, implementation and effectiveness (59\%), information through careful PR research is used to guide planning, evaluate results and direct follow ups $(62 \%)$, $\mathrm{PR}$ research needs a basis as to be a little more than a low level in support of some management decisions (67\%), PR being an art of persuasion, thus to influence people it's obviously helpful to know how people think and the manner they react to particular circumstances $(63 \%)$.

Table 2. Research Activity involved in

\begin{tabular}{|c|c|c|c|c|c|}
\hline Activity involved in & Majorly Involved & Involved & $\begin{array}{c}\text { Minimally } \\
\text { Involved }\end{array}$ & Not Involved & Total \\
\hline i)Fact Gathering & $22(13.25 \%)$ & $63(37.95 \%)$ & $39(23.49 \%)$ & $42(25.3 \%)$ & $166(100 \%)$ \\
\hline ii) Evaluation of Results & $15(9.03 \%)$ & $23(13.85 \%)$ & $57(34.33 \%)$ & $71(42.77 \%)$ & $166(100 \%)$ \\
\hline iii)Program Planning & $9(5.42 \%)$ & $12(7.22 \%)$ & $56(33.73 \%)$ & $89(53.61 \%)$ & $166(100 \%)$ \\
\hline iv) Implementation & $28(16.86 \%)$ & $89(53.61 \%)$ & $26(15.66 \%)$ & $23(13.85 \%)$ & $166(100 \%)$ \\
\hline
\end{tabular}

Source: Respondents scores, 2008

Table 3. Effect of PR Principles in the Management of KPD

\begin{tabular}{|c|c|c|c|c|c|c|}
\hline PR Research & $\begin{array}{c}\text { Strongly } \\
\text { Agree }\end{array}$ & Agree & Neutral & Disagree & $\begin{array}{l}\text { Strongly } \\
\text { Disagree }\end{array}$ & Total \\
\hline $\begin{array}{l}\text { The PR officer studies the public relations results } \\
\text { and evaluates the programs planning } \\
\text { implementation and effectiveness. }\end{array}$ & $\begin{array}{c}46 \\
(27.72 \%)\end{array}$ & $\begin{array}{c}59 \\
(35.45 \%)\end{array}$ & $\begin{array}{c}30 \\
(18.07 \%)\end{array}$ & $\begin{array}{c}24 \\
(14.46 \%)\end{array}$ & $\begin{array}{c}7 \\
(4.21 \%)\end{array}$ & $\begin{array}{c}166 \\
(100 \%)\end{array}$ \\
\hline $\begin{array}{l}\text { Information through careful PR research is used to } \\
\text { guide planning evaluate results and direct follow } \\
\text { ups }\end{array}$ & $\begin{array}{c}53 \\
(31.93 \%)\end{array}$ & $\begin{array}{c}62 \\
(37.35 \%)\end{array}$ & $\begin{array}{c}24 \\
(14.46 \%)\end{array}$ & $\begin{array}{c}18 \\
(10.84 \%)\end{array}$ & $\begin{array}{c}9 \\
(5.42 \%)\end{array}$ & $\begin{array}{c}166 \\
(100 \%)\end{array}$ \\
\hline $\begin{array}{l}\text { PR research needs a basis as to be a little more than } \\
\text { a low level activity in support of some management } \\
\text { decisions }\end{array}$ & $\begin{array}{c}48 \\
(29.09 \%)\end{array}$ & $\begin{array}{c}67 \\
(40.61 \%)\end{array}$ & $\begin{array}{c}30 \\
(18.07 \%)\end{array}$ & $\begin{array}{c}15 \\
(9.09 \%)\end{array}$ & $\begin{array}{c}5 \\
(3.14 \%)\end{array}$ & $\begin{array}{c}166 \\
(100 \%)\end{array}$ \\
\hline $\begin{array}{c}\text { PR being an art of persuasion, thus to influence } \\
\text { people its obviously helpful to know how people } \\
\text { think and the manner they react to particular } \\
\text { circumstances. }\end{array}$ & $\begin{array}{c}39 \\
(23.49 \%)\end{array}$ & $\begin{array}{c}63 \\
(37.95 \%)\end{array}$ & $\begin{array}{c}34 \\
(20.48 \%)\end{array}$ & $\begin{array}{c}8 \\
(4.83 \%)\end{array}$ & $\begin{array}{c}22 \\
(13.25 \%)\end{array}$ & $\begin{array}{c}166 \\
(100 \%)\end{array}$ \\
\hline
\end{tabular}

Source: Respondents scores, 2008 


\subsection{Effect of Planning on the Management of KPD}

In investigating the effect of planning on management it was considered important to find out who is involved in the planning process and how often planning activities are carried out. This helps in understanding the levels of efficiency and effectiveness as well as the policy formulation and implementation process. The study therefore sought to find out who in the departmental hierarchy was involved in planning activity and the findings were illustrated in Figure 4 below.

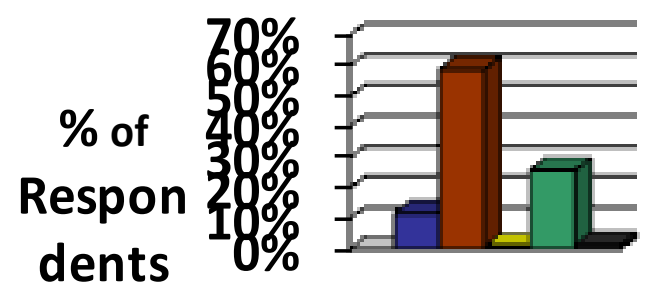

Figure 4. Involvement in planning activity

Figure 4 above illustrates that majority $(59.03 \%, \mathrm{n}=98)$ of the respondents stated that only the top level management was involved in planning activities while $25.9 \%(n=43)$ stated that it was both the top and middle level management and $\mathrm{s} 12.4 \%(\mathrm{n}=20)$ stated that it was specialized PR team that was involved. This depicts that it was the Top level management that was in most cases involved in planning activities in KPD.

Having found out whom in the organizational structure was involved in the planning process the study sought to investigate how often planning activities were carried out in the department and the findings were as illustrated in Figure 5 below.

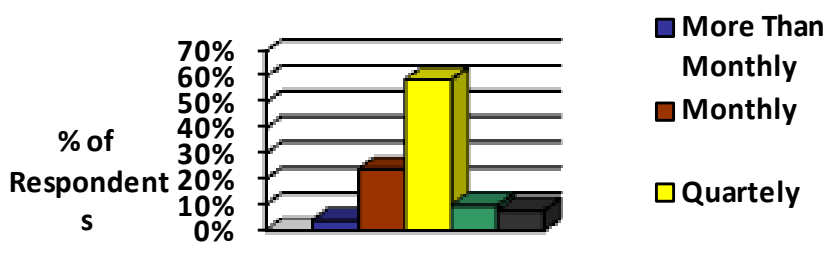

Figure 5. How often Planning activities are carried out

Figure 5 above illustrates that majority $(59.03 \%, n=98)$ of the respondents stated that planning activities took place mostly on a quarterly basis.

After establishing the frequency of planning activities took place mostly on a quarterly basis, the study also sought to find out the respondents opinion on the efficiency and effectiveness of the planning process as well as policy formulation and implementation process and the findings were as shown in the Likert scale of Table 4 below.

Table 4. Rating of planning and policy formulation and implementation

\begin{tabular}{|c|c|c|c|c|c|c|}
\hline Rating & $\begin{array}{l}\text { Very } \\
\text { Good }\end{array}$ & Good & Average & Poor & Very Poor & Total \\
\hline $\begin{array}{c}\text { Efficiency of } \\
\text { planning process }\end{array}$ & $\begin{array}{c}4 \\
(2.41 \%) \\
\end{array}$ & $\begin{array}{c}12 \\
(7.23 \%) \\
\end{array}$ & $\begin{array}{c}98 \\
(59 \%) \\
\end{array}$ & $\begin{array}{c}38 \\
(22.89 \%) \\
\end{array}$ & $\begin{array}{c}14 \\
(8.43 \%) \\
\end{array}$ & $\begin{array}{c}166 \\
(100 \%) \\
\end{array}$ \\
\hline $\begin{array}{l}\text { Effectiveness of } \\
\text { planning process }\end{array}$ & $\begin{array}{c}4 \\
(2.41 \%)\end{array}$ & $\begin{array}{c}18 \\
(10.84 \%)\end{array}$ & $\begin{array}{c}102 \\
(61.45 \%)\end{array}$ & $\begin{array}{c}30 \\
(18.07 \%)\end{array}$ & $\begin{array}{c}12 \\
(7.23 \%)\end{array}$ & $\begin{array}{c}166 \\
(100 \%)\end{array}$ \\
\hline $\begin{array}{c}\text { Policy } \\
\text { Formulation }\end{array}$ & $\begin{array}{c}4 \\
(2.41 \%) \\
\end{array}$ & $\begin{array}{c}8 \\
(4.82 \%) \\
\end{array}$ & $\begin{array}{c}92 \\
(55.42 \%) \\
\end{array}$ & $\begin{array}{c}44 \\
(26.5 \%) \\
\end{array}$ & $\begin{array}{c}18 \\
(10.84 \%) \\
\end{array}$ & $\begin{array}{c}166 \\
(100 \%) \\
\end{array}$ \\
\hline $\begin{array}{c}\text { Policy } \\
\text { Implementation }\end{array}$ & $\begin{array}{c}6 \\
(3.61 \%)\end{array}$ & $\begin{array}{c}12 \\
(7.23 \%)\end{array}$ & $\begin{array}{c}104 \\
(62.65 \%)\end{array}$ & $\begin{array}{c}32 \\
(19.27 \%)\end{array}$ & $\begin{array}{c}12 \\
(7.23 \%)\end{array}$ & $\begin{array}{c}166 \\
(100 \%)\end{array}$ \\
\hline
\end{tabular}

Table 4 above shows that majority of the respondents rated as average the efficiency of planning process $(59 \%, n=98)$, effectiveness of the planning process $(61.45 \%, n=102)$, policy formulation $(55.42 \%, n=92)$ and policy implementation $(62.65 \%, \mathrm{n}=104)$. In general the efficiency of the planning process could be considered to be average. Having established that these factors were rated to be not satisfactory, the study further sought to determine the effect of planning on the management of KPD. The results were as shown in the Likert scale of Table 5 below.

Table 5. Effect of planning on the management of KPD

\begin{tabular}{|c|c|c|c|c|c|c|}
\hline Planning in Management & $\begin{array}{l}\text { Strongly } \\
\text { Agree }\end{array}$ & Agree & Neutral & Disagree & $\begin{array}{l}\text { Strongly } \\
\text { Disagree }\end{array}$ & Total \\
\hline $\begin{array}{c}\text { PR planning provides a sense of direction, focus and helps an } \\
\text { organization to evaluate their progress }\end{array}$ & $\begin{array}{c}45 \\
(27.11 \%)\end{array}$ & $\begin{array}{c}67 \\
(40.36 \%)\end{array}$ & $\begin{array}{c}31 \\
(18.67 \%)\end{array}$ & $\begin{array}{c}18 \\
(10.84 \%)\end{array}$ & $\begin{array}{c}5 \\
(3.02 \%) \\
\end{array}$ & $\begin{array}{c}166 \\
(100 \%)\end{array}$ \\
\hline $\begin{array}{l}\text { PR planning is an activity which involves decisions about end means, } \\
\text { conducts and results }\end{array}$ & $\begin{array}{c}54 \\
(33.13 \%) \\
\end{array}$ & $\begin{array}{c}60 \\
(36.81 \%)\end{array}$ & $\begin{array}{c}13 \\
(7.98 \%) \\
\end{array}$ & $\begin{array}{c}24 \\
(14.72 \%) \\
\end{array}$ & $\begin{array}{c}12 \\
(7.36 \%)\end{array}$ & $\begin{array}{c}166 \\
(100 \%)\end{array}$ \\
\hline $\begin{array}{c}\text { PR planning is activity that takes place against the background of the } \\
\text { organization external environment }\end{array}$ & $\begin{array}{c}37 \\
(22.29 \%) \\
\end{array}$ & $\begin{array}{c}82 \\
(49.40 \%) \\
\end{array}$ & $\begin{array}{c}19 \\
(11.45 \%)\end{array}$ & $\begin{array}{c}17 \\
(10.24 \%)\end{array}$ & $\begin{array}{c}11 \\
(6.62 \%)\end{array}$ & $\begin{array}{c}166 \\
(100 \%)\end{array}$ \\
\hline PR effectiveness depends on good planning & $\begin{array}{c}47 \\
(28.31 \%) \\
\end{array}$ & $\begin{array}{c}78 \\
(46.99 \%)\end{array}$ & $\begin{array}{c}31 \\
(18.67 \%)\end{array}$ & $\begin{array}{c}7 \\
(4.22 \%) \\
\end{array}$ & $\begin{array}{c}3 \\
(1.81 \%)\end{array}$ & $\begin{array}{c}166 \\
(100 \%)\end{array}$ \\
\hline $\begin{array}{l}\text { Good planning is the best way to practice preventive rather than } \\
\text { remedial PR }\end{array}$ & $\begin{array}{c}38 \\
(22.89 \%)\end{array}$ & $\begin{array}{c}65 \\
(39.16 \%)\end{array}$ & $\begin{array}{c}25 \\
(15.06 \%)\end{array}$ & $\begin{array}{c}20 \\
(12.05 \%)\end{array}$ & $\begin{array}{c}18 \\
(10.84 \%)\end{array}$ & $\begin{array}{c}166 \\
(100 \%)\end{array}$ \\
\hline
\end{tabular}


Table 5 above shows that the means for PR planning provides a sense of direction, focus and helps an organization to evaluate their progress; PR planning is an activity which involves decisions about ends, means, conducts and results. PR planning is an activity that takes place against the background of the organizational external environment, PR planning is a management activity which begins by defining the aims and objective of an organization, PR effectiveness depends on good planning and good planning is the best way to practice preventive rather than remedial PR. This is supported by the fact that the mean scores fall in the Agree category $(3.872,4.01,4.342,3.891,4.023$ and 3.453).

\subsection{Effects of Counseling Roles of PR on the Management of KPD}

In order to determine the Effects of Counseling Roles of PR on Management it was found important to find out those involved in counseling management, the channels of communication used and their effectiveness. This is because an appropriate communications program is essential in highlighting the organizations positive accomplishments. The study therefore sought to find out who is involved in counseling management on PR and the findings were as illustrated in Figure 4.6 below.

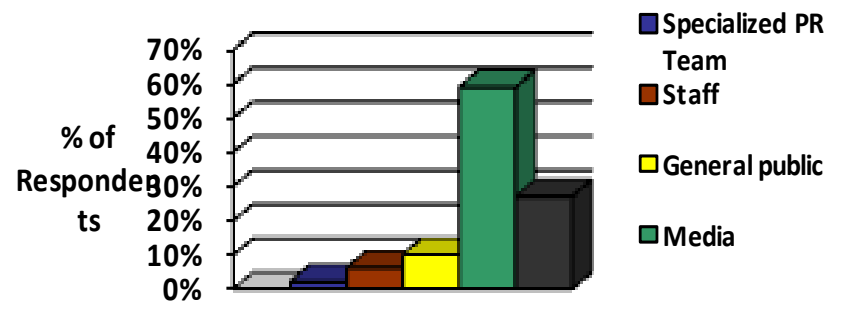

Figure 6. Those involved in counseling management on PR

Figure 6 above illustrates that majority $(59.03 \%, \mathrm{n}=98)$ of the respondents stated the media as the most involved in informing management on PR.

Having established the media as the most involved in informing management on PR the study also sought to find out the channels used in communicating PR issues and the findings were as illustrated in Figure 7 below.

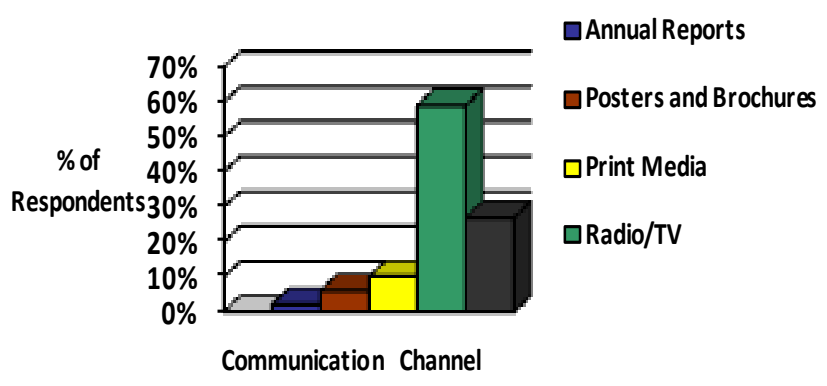

Figure 7. Channels used in communicating PR issues

Figure 7 above illustrates that majority of the respondents stated Radio/TV as the communication channel mostly used as reported by $59.03 \%(n=98)$. This attributed to the fact that the media was the most involved in informing management on PR.

Having found out the channels of communication used the study sought to establish the effectiveness of these channels in improving PR and the findings were as illustrated in Figure 4.8 below.

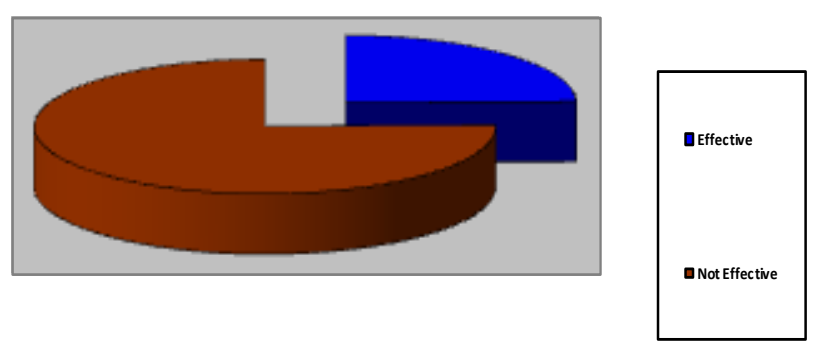

Source: Respondents scores, 2008

Figure 8. Effectiveness of Communication channels in improving PR

Figure 8 above illustrates that majority of the respondents $(75.3 \%, \mathrm{n}-125)$ considered the channels of communication used in informing management on PR were not effective in improving PR. This indicates that the media did not provide any improvement in PR.

The study also sought to determine how the counseling role of PR affects the management of KPD. The descriptive statistics for various aspects investigated were computed and the findings presented in Table 6 below.

Table 6. Effect of PR Counseling on the Management of KPD

\begin{tabular}{|c|c|c|c|c|c|c|}
\hline Counseling Role of PR & $\begin{array}{l}\text { Strongly } \\
\text { Agree }\end{array}$ & Agree & Neutral & Disagree & $\begin{array}{l}\text { Strongly } \\
\text { Disagree }\end{array}$ & Total \\
\hline $\begin{array}{l}\text { Counseling enables individual to get their problems into perspective } \\
\text { and to see what they themselves can do to solve them }\end{array}$ & $\begin{array}{c}45 \\
(27.11 \%) \\
\end{array}$ & $\begin{array}{c}65 \\
(39.16 \%) \\
\end{array}$ & $\begin{array}{c}20 \\
(12.05 \%)\end{array}$ & $\begin{array}{c}23 \\
(13.86 \%) \\
\end{array}$ & $\begin{array}{c}13 \\
(7.83) \\
\end{array}$ & $\begin{array}{c}166 \\
(100 \%)\end{array}$ \\
\hline $\begin{array}{l}\text { Modern PR calls for people with a holistic view of business who can } \\
\text { act as management advisers on a variety of issues }\end{array}$ & $\begin{array}{c}34 \\
(8.43 \%)\end{array}$ & $\begin{array}{c}76 \\
(45.78 \%) \\
\end{array}$ & $\begin{array}{c}29 \\
(17.47 \%)\end{array}$ & $\begin{array}{c}13 \\
(7.83 \%) \\
\end{array}$ & $\begin{array}{c}14 \\
(8.43 \%) \\
\end{array}$ & $\begin{array}{c}166 \\
(100 \%)\end{array}$ \\
\hline $\begin{array}{l}\text { PR seeks to give continuous information to the people regarding laws, } \\
\text { regulations and such matters that affect daily life of the citizens }\end{array}$ & $\begin{array}{c}23 \\
(13.86 \%)\end{array}$ & $\begin{array}{c}57 \\
(34.33 \%) \\
\end{array}$ & $\begin{array}{c}65 \\
(39.16 \%)\end{array}$ & $\begin{array}{c}21 \\
(12.65 \%)\end{array}$ & $\begin{array}{c}0 \\
(0 \%) \\
\end{array}$ & $\begin{array}{c}166 \\
(100 \%)\end{array}$ \\
\hline $\begin{array}{l}\text { PR advises the management at all levels regarding likely reactions of } \\
\text { the people to the proposed laws and policies of an organization }\end{array}$ & $\begin{array}{c}38 \\
(22.89 \%)\end{array}$ & $\begin{array}{c}47 \\
(28.31 \%)\end{array}$ & $\begin{array}{c}57 \\
(34.33 \%)\end{array}$ & $\begin{array}{c}16 \\
(9.64 \%)\end{array}$ & $\begin{array}{c}8 \\
(4.82 \%)\end{array}$ & $\begin{array}{c}166 \\
(100 \%)\end{array}$ \\
\hline $\begin{array}{l}\text { Counseling as a PR tool entails advising management on what needs to } \\
\text { be done and the expected reactions towards various proposals }\end{array}$ & $\begin{array}{c}23 \\
(13.86 \%)\end{array}$ & $\begin{array}{c}67 \\
(40.36 \%)\end{array}$ & $\begin{array}{c}40 \\
(24.09 \%)\end{array}$ & $\begin{array}{c}34 \\
(20.84 \%)\end{array}$ & $\begin{array}{c}2 \\
(1.21 \%)\end{array}$ & $\begin{array}{c}166 \\
(100 \%)\end{array}$ \\
\hline
\end{tabular}

Source: Respondents scores, 2008 
The findings presented in Table 6 above show that most respondents agreed with the fact that counseling enables individuals to get their problems into perspective and see what they themselves can do to solve them, PR calls for people with a holistic view of business who can act as management advisers on a variety of issues. Counseling as a PR tool had a mean score of 3.74, 4.15 and 3.85 respectively. This implies that counseling enables individuals to get their problems into perspective, calls for people with holistic knowledge of the business who can act as business advisers on a variety of issues and it entails advising on what needs to be done and expected reactions from the various proposals.

In addition, most of the respondents were neutral to the fact that PR seeks to give continuous information to the people regarding the laws, regulations and such matters that affect daily life of the citizen, PR advises the management at all levels regarding the likely reactions of the people to the proposed law and policies of an organization as the means were 3.08 and 3.16 respectively.

\subsection{Anticipatory Roles on the Management of KPD}

Effective PR, as mentioned elsewhere in this study, ensures that the public is no longer ignorant of the organizations good points. In anticipating public opinion towards the management of KPD it was considered important to gauge the public opinion, find out its reason and the areas of management that are a source of crisis in PR. The study therefore sought to find out the respondents views on the public opinion towards KPD and the findings were as illustrated in Figure 9 below.

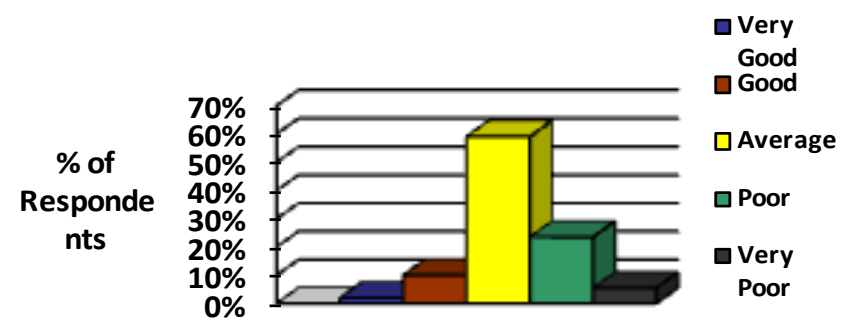

Source: Respondents scores, 2008

Figure 9. View on the public opinion towards KPD

Figure 9 above illustrates that the public opinion toward KPD fell between average $(59 \%, \mathrm{n}=98)$ and poor $(23.5 \%$, $\mathrm{n}=39$ ). It could however be argued that since this study was conducted internally among staff the figures would have gravitated towards 'poor' had the same study been conducted externally.

Having established the public opinion towards KPD the study sought to find out the respondents views on what had been the major cause of past crisis in public relations and the findings were as illustrated in Figure 10 below.

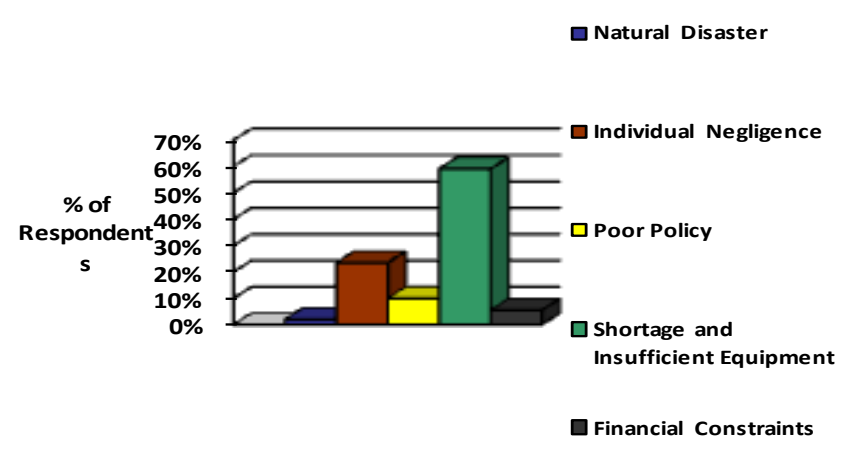

Source: Respondents scores, 2008

Figure 10. Major cause of Past Crisis

Figure 10 above illustrates that the major cause of past crisis in public opinion was to a greater extent cause by shortages and insufficient equipment $(59 \%, \mathrm{n}=98)$ and a considerable proportion stating Individual negligence $(23.5 \%, \mathrm{n}=39)$.

After establishing the major cause of past crisis the study sought to find out which areas of management had in the past been a source of crisis in public relations and the findings were as illustrated in Figure 11 below.

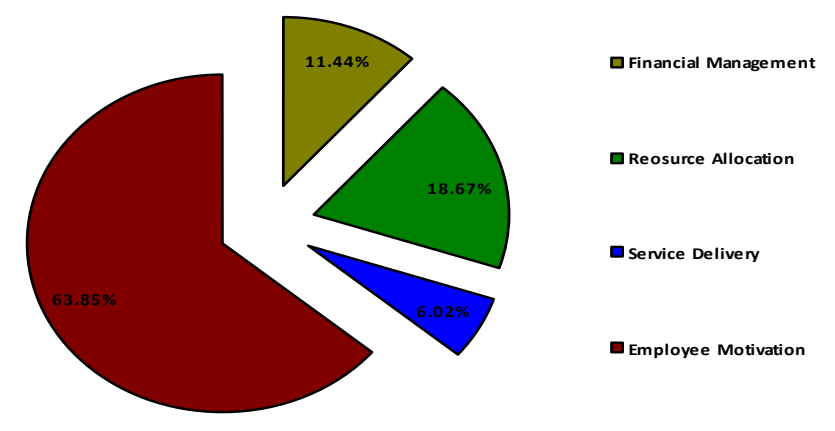

Source: Respondents scores, 2008

Figure 11. Areas in Management that are sources of past crisis in PR

Figure 11 above illustrates that majority $(63.85 \%, n=106)$ of the respondents stated resource allocation as the area of management that has been the source of past crisis in PR while employee motivation was reported by $18.67 \%(n=31)$ and Service delivery by $11.44 \%(\mathrm{n}=19)$. This could be the reason why shortages and insufficient equipment was highlighted as the major cause of past crisis established earlier in the report.

The study further sought to determine how the anticipatory roles of PR affect the management of KPD. The percentages, frequencies, means and standard deviations for the various aspects investigated were computed and the results tabulated in Table 7 below. 
Table 7. Anticipatory Roles on Management of KPD

\begin{tabular}{|c|c|c|c|c|c|c|}
\hline Anticipatory Role & $\begin{array}{l}\text { Strongly } \\
\text { Agree }\end{array}$ & Agree & Neutral & Disagree & $\begin{array}{l}\text { Strongly } \\
\text { Disagree }\end{array}$ & Total \\
\hline $\begin{array}{l}\text { Effective PR will ensure that the public which is important to the } \\
\text { organization is no longer ignorant to the organization's good points. }\end{array}$ & $\begin{array}{r}57 \\
(35.621 \%) \\
\end{array}$ & $\begin{array}{c}46 \\
(28.75 \%) \\
\end{array}$ & $\begin{array}{c}23 \\
(14.38 \%) \\
\end{array}$ & $\begin{array}{c}27 \\
(16.88 \%) \\
\end{array}$ & $\begin{array}{c}7 \\
(4.37 \%) \\
\end{array}$ & $\begin{array}{c}166 \\
(100 \%) \\
\end{array}$ \\
\hline $\begin{array}{l}\text { PR officer task includes identifying how the public will react to } \\
\text { particular events. }\end{array}$ & $\begin{array}{c}45 \\
(27.78 \%) \\
\end{array}$ & $\begin{array}{c}60 \\
(36.14 \%) \\
\end{array}$ & $\begin{array}{c}18 \\
(11.11 \%) \\
\end{array}$ & $\begin{array}{c}30 \\
(18.52 \%) \\
\end{array}$ & $\begin{array}{c}9 \\
(6.45 \%) \\
\end{array}$ & $\begin{array}{c}166 \\
(100 \%) \\
\end{array}$ \\
\hline $\begin{array}{l}\text { PR techniques are used to reduce negative association as well as } \\
\text { create positive ones. }\end{array}$ & $\begin{array}{c}67 \\
(40.36 \%) \\
\end{array}$ & $\begin{array}{c}56 \\
(33.73 \%) \\
\end{array}$ & $\begin{array}{c}34 \\
(20.48) \\
\end{array}$ & $\begin{array}{c}4 \\
(2.41 \%) \\
\end{array}$ & $\begin{array}{c}5 \\
(3.02 \%) \\
\end{array}$ & $\begin{array}{c}166 \\
(100 \%) \\
\end{array}$ \\
\hline $\begin{array}{c}\text { PR officer helps the public to become more knowledgeable about the } \\
\text { organization and its perspectives. }\end{array}$ & $\begin{array}{c}52 \\
(31.32 \%) \\
\end{array}$ & $\begin{array}{c}66 \\
(39.76 \%) \\
\end{array}$ & $\begin{array}{c}27 \\
(16.27 \%) \\
\end{array}$ & $\begin{array}{c}15 \\
(9.04 \%) \\
\end{array}$ & $\begin{array}{c}6 \\
(3.61 \%) \\
\end{array}$ & $\begin{array}{c}166 \\
(100 \%) \\
\end{array}$ \\
\hline $\begin{array}{l}\text { PR strategies should enhance motivation and ability to process } \\
\text { information }\end{array}$ & $\begin{array}{c}4 \\
(2.37 \%)\end{array}$ & $\begin{array}{c}28 \\
(16.87 \%)\end{array}$ & $\begin{array}{c}45 \\
(27.21 \%)\end{array}$ & $\begin{array}{c}66 \\
(39.78 \%)\end{array}$ & $\begin{array}{c}23 \\
(13.86 \%)\end{array}$ & $\begin{array}{c}166 \\
(100 \%) \\
\end{array}$ \\
\hline
\end{tabular}

Source: Respondents scores, 2008

The findings presented in Table 7 above show that most respondents agreed that effective PR will ensure that the public that is important to the organization is no longer ignorant to the organizations good points, PR officers task includes to identify how the public will react to particular events, PR techniques are used to reduce negative association as well as create positive ones and PR officer helps the public to become more knowledgeable about the organization and its perspectives as the means were 4.342 , $3.864,4.356$ and 3.645 respectively. This implies that the management of KPD has effective PR which ensures that the public that is important to KPD is no longer ignorant to KPD good points, KPD PR officers task includes identification of how the public reacts to particular events, KPD PR uses PR techniques to reduce negative associations as well as create positive ones and KPD PR officer helps the public to become more knowledgeable about KPD as an organization and its perspectives.

Further, most of the respondents, disagreed that PR strategies should enhance motivation and ability to process information with a mean of 2.475. This implies that KPD PR strategies should be improved to enhance motivation and ability to process information.

\section{Conclusions and Recommendations}

The study revealed that though most respondents agreed that fact gathering is an important activity in evaluation research and most were involved in the activity, the research instrument that was mostly used was Radio/TV in contrast with other suggested instruments like interviews, from library material and through informal conversation. It was also established that most respondents were not involved in evaluation of results and in program planning even though they agreed that good management depended on information through careful research, a good PR basis and how people think and the manner they react to particular circumstances.

Though it was generally agreed that PR planning provides a sense of direction and focus, involves decisions about ends, means, conduct and result, a considerable proportion of respondents stated that respondents reported that only top level management was involved in planning activities while planning activities took place generally on a quarterly basis.
Though the purpose of PR is to establish and maintain goodwill and mutual understanding between an organization and its publics the effectiveness and efficiency of the planning process including policy formulation and implementation was considered to be at best average.

The study revealed that the media was mostly involved in informing management on PR through the use of Radio/TV. However the effectiveness of this communication channel in improving PR was considered to be not effective. It could therefore be concluded that the media was not effective in enabling people to get their problems into perspective and to see what they themselves can do to solve them. While it was generally agreed that for effective PR there should be people with a holistic view of business who can act as management advisers on a variety of issues it could be concluded that the media lacked a holistic view of KPD.

Since the general view of public opinion towards KPD was considered average while the major cause of past crisis in PR was shortage and insufficient equipment and is related to resource allocation there seemed to be a lack of motivation and ability to process information that addresses concerns and clarifies misunderstanding. While it was generally agreed that effective PR ensures that the public is not ignorant of the organizations good points and that PR techniques are used to reduce negative association as well as create positive ones the average public opinion indicated that the effectiveness of PR was also average signifying a considerable level of ignorance among the public of the organizations good points.

The study recommends that fact gathering instruments like conducting of interviews, literature review, observation and informal conversations be used so as to be able to collect appropriate data. This is because Radio/TV alone cannot offer holistic information on the PR situation. It would thus be important to conduct full surveys and to produce reports so as to accurately present the PR situation. It is also suggested that as many staff as possible be involved in all processes of research including evaluation of results and program planning so as to establish a sense of ownership which will create enthusiasm in implementation.

The study also recommends that planning activities involve a specialized PR team. This would be a team specialized in effective communication, research and planning techniques. The PR team would also be working 
with all levels of the organization hierarchy. This would be useful in improving the effectiveness and efficiency of the planning process as all staff would be more aware of the goals and aspirations of the organization.

The study further recommends that management rely on other channels of information concerning PR and not just the media since the media is most likely to have its own vested interests that could be contrary to those of the organization. A specialized PR team would be more effective as their goals and objectives would be entirely geared towards the benefit of the organization. Methods that involve direct contact with the clientele would also offer valuable first hand information that would help management get their problems into perspective and to see what they themselves can do to solve them.

Finally the study recommends that KPD management address its resource allocation problem that has led to shortages and insufficient equipment. Since KPD is not autonomous but relies on the decisions of a provincial authority and ultimately on the ministry of internal security, it may be difficult to push for reforms in this area. It is however worth noting that being aware and constantly communicating these drawbacks may result in some realistic view from the public.

The study has established several areas of research that call for further investigation. This include; the role of communication in management of KPD; the role of policy formulation and implementation in KPD; the role of police spokesman, management and members of the public in the decision making process.

\section{REFERENCES}

[1] Baines, P. (2004). Public relations: Contemporary issues \& techniques. New Jersey: Prentice hall.

[2] Black, S. (1972). The role of public relations in management. London; Pitman Publishing.

[3] Black, S. (1991). Practical public relations (4 ${ }^{\text {th }}$ rev. ed.). London: Universal Book stall.

[4] Broom, G.M., \& Dozier, D.M. (1990). Using research in public relations: Application to programme management. New Jersey: Prentice Hall.
[5] An analysis of the public relations role of the police public information officer. Police Quarterly, 2002. Volume 5: No.2.

[6] Christ, P. (2009). Know this: Marketing Basics.(online). Available: www.knowthis.com/books/marketing -basics/ (26th January, 2010).

[7] Cole, G.A. (1979) Personnel management. New Jersey: Prentice Hall.

[8] Cutlip, S.M, Center, A.H., \& Broom, G.M (1985). Effective public relations ( $6^{\text {th }}$ rev. ed). New Jersey: Prentice Hall.

[9] Drucker, P. (1954). The practice of management. Butterworth : Heinemann.

[10] Fayol, H. (1987). General and industrial management: Henry Fayol's classic revised by Irwin Gray. Belmont, CA: David S. Lake Publishers

[11] Grunig, J.E. and Hunt, T.T. (1984). Managing public relations. London: Wadsworth Publishing.

[12] Howard, W. (1992). The practice of public relations $\left(3^{\text {rd }}\right.$ rev. ed.). Butterworth: Heinemann.

[13] Jefkins, F. (1994). Public relations techniques , ( $2^{\text {nd }}$ rev. ed.). Butterworth: Heinemann

[14] Jefkins, F. (1998). Public relations ( $5^{\text {th }}$ rev. ed). New Jersey: Prentice Hall.

[15] Kenya Police Standing Orders. 1985. Kenya: Government press.

[16] Kisumu Central Police Station. 2008. Police occurrence book. August 2008. (At the Kisumu Central Police Station reception).

[17] Kisumu Central Police Station. 2008. Kenya Police Cell Register book, August 2008. (At the Kisumu Central Police Station reception).

[18] Lesley, J. (1991). The handbook of public relations and communication, $\left(4^{\text {th }}\right.$ rev.ed.). UK: McGraw- Hill.

[19] Michael, A. (2008). Strategic human resource management: A guide to action, $\left(4^{\text {th }}\right.$ rev. ed.). London: Kogan Page Limited.

[20] Norman, A.H. (1995). Strategic public relations. London: Macmillan Press Limited.

[21] Otis, B. Aronoff, C. \& Lattimore, D. (1997). Public relations: The profession and the practice, $\left(4^{\text {th }}\right.$ rev. ed.). UK. McGraw Hill.

[22] Puri, G.P. (1995). Public relations for all, ( $2^{\text {nd }}$ rev. ed.). India: Indian Institute of Management and Services. 